\title{
INTERNAL CONTROL: METHODOLOGICAL DISTINCTIONS OF COUNTERPARTY CREDITWORTHINESS CHECKS
}
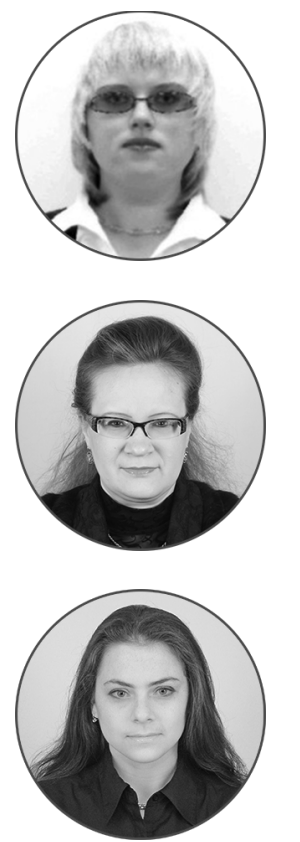

\section{Article history:}

Received 3 August 2018 Received in revised form 8 August 2018

Accepted 10 August 2018

Translated 10 December 2018

Available online 24 December 2018

JEL classification: M42

Keywords: internal control, accounts receivable, counterparty

\author{
Elena N. SHATINA \\ National Research Lobachevsky State University of Nizhny Novgorod (UNN), \\ Nizhny Novgorod, Russian Federation \\ shatina79@inbox.ru

\section{Svetlana V. KOZMENKOVA} \\ National Research Lobachevsky State University of Nizhny Novgorod (UNN), \\ Nizhny Novgorod, Russian Federation \\ skozmenkova@yandex.ru \\ Corresponding author
}

\section{Elina B. FROLOVA}

National Research Lobachevsky State University of Nizhny Novgorod (UNN), Nizhny Novgorod, Russian Federation elina_firman@mail.ru

\begin{abstract}
Subject This article deals with the issues related to the methodology of client acceptance procedures within the internal control framework.

Objectives The article aims to develop methodological approaches to perform internal control when checking the counterparty creditworthiness.

Methods We used the methods of comparative analysis and systematization.

Results The article proposes a method for internal control when checking counterparties' financial reliability preceding the conclusion of a contract, including working papers of the controller, mitigating the business risk.

Conclusions and Relevance The proposed algorithm for counterparty creditworthiness checks and forms of working documents will help enterprises and entrepreneurs get information about contractors at the stage of contracting, which would reduce the default risk in the future. The findings can be applied in the theory and practice of internal and external control during counterparty creditworthiness checks, as well as in the master's degree educational process in the field of Economics and Economic Expert Analysis.
\end{abstract}

(c) Publishing house FINANCE and CREDIT, 2018

The editor-in-charge of this article was Irina M. Vechkanova

Authorized translation by Irina M. Vechkanova 
Selling its finished products, goods, services, any business entity deals with counterparties (Latin contrahēns 'collecting, accomplishing, contracting'). Counterparties are persons or entities bound by obligations under a common agreement and cooperating in compliance with it ${ }^{1}$. Such relationships result in accounts receivable or payable.

It is important for any business entity to manage its accounts receivable since it is able to plan its cash flows assuming that amounts due will be timely repaid. In the mean time, business entities need to manage their accounts payable as well since acquiring entities expect suppliers to timely deliver property, work and services. If suppliers fail to perform their contractual obligations in a timely manner, the production process will stall, inducing other consequences and affecting the continuity of business operations.

Accounts receivable are managed so as to secure cash flows or other property and settle accounts with counterparties within the timelines stipulated in the contract. Managing its accounts receivable, the business entity should ensure the quality of its accounting and effective analysis. These challenging issues are examined in proceedings by A. Arens and J. Loebbecke ${ }^{2}$, V.B. Ivashkevich [1], L.I. Kulikova [2], G.S. Klychova and Z.Z. Khamidullina [3, 4], S.A. Kemaeva $[5,6]$, L.B. Sungatullina [7]. Distinctive aspects of accounts receivable management are studied by N.V. Gorshkova and O.V. Khmeleva [8].

Distinctive aspects of accounting, analysis and accounts payable management are investigated by I.V. Artemova [9], E.A. Vedernikova [10], V.A. Grebennikova and A.N. Ponchishkina [11], V.V. Kopeina [12], N.A. Markova [13].

Auditing and internal control screen accounts receivable and payable. Respective studies are performed by N.G. Sapozhnikova and O.Yu. Trunaeva [14], N.N. Kovaleva, L.V. Ermakova and A.E. Mel'guya [15], M.A. Chaplygina, G.A. Pol'skaya and

\footnotetext{
${ }^{\dagger}$ For the source article, please refer to: Шатина Е.Н., Козменкова С.В., Фролова Э.Б. Внутренний контроль: методические особенности проверки контрагентов на благонадежность. Международный бухгалтерский учет. 2018. Т. 21. № 8. С. 904-916. URL: https://doi.org/10.24891/ia.21.8.904

${ }^{1}$ Raizberg B.A., Lozovskii L.Sh., Starodubtseva E.B. Sovremennyi ekonomicheskii slovar' [Contemporary dictionary of economics]. Moscow, INFRA-M Publ., 1997, 496 p.

${ }^{2}$ Arens A., Loebbecke J. Audit [Auditing: An Integrated Approach]. Moscow, Finansy i Statistika Publ., 1995, 560 p.
}

N.I. Vinogradova

$[16]$

N.O. Mikhalenok

and

O.V. Shnaider [17].

Business entities may perform preliminary, ongoing and follow-up control of the transaction time. Preliminary control takes place before a transaction, ongoing control coincides in time with a transaction, and follow-up control goes after a transaction.

Scholarly proceedings mainly discuss the audit of financial statements, external and internal control which are usually of ongoing or follow-up nature. We assign the highest importance to preliminary internal control. Contractual policy is studied by B.A. Shakhmanova as an aspect to be audited [18]. In our opinion, business entity should necessarily conduct the preliminary internal control of counterparties in terms of their creditworthiness.

The counterparty creditworthiness check is a crucial step in the contractual process. It gets especially important if the contract is intended to be long-term and entail substantial financial costs. We believe the counterparty creditworthiness check is the responsibility of the internal control department.

Unreliable entities (the so called fly-by-night organizations) affect all parties involved. The State collects less tax. Their counterparties have to face controlling authorities' interrogations concerning such organizations. Thee issues usually turn to be very costly for business entities, entailing additionally charged taxes, penalties, and denied VAT refunds. Counterparty creditworthiness checks may, if needed, help produce evidence of the business entity's prudence in documenting its business relationships with the counterparty.

General information about counterparties is in public sources on the Internet. For this, business entities need to know identification number of a tax payer (in Russian 'INN'). Publicly available sources are presented in Table 1.

Referring to the sources, we examine the specifics of checking the counterparties which are debtors of an agricultural entity in the Nizhny Novgorod Oblast and buyers of agricultural products for canteens and bakery production.

The Uniform State Register of Legal Entities (abbreviated in Russian as 'EGRUL') provides information on the incorporation date, size of authorized capital, registered address, CEO's details, 
types of activities, dates of updates to the EGRUL. Table 2 reflects the proposed form of a working document the internal controller uses.

Having checked commercial court case files, we found out that PAO Machinebuilding Plant as one of the analyzable counterparties is sued in the court. The proposed form of the internal controller's working document, Commercial Court Case Files Check, (Table 3) shows the findings we made in scrutinizing the debtors.

Therefore, we should analyze financial statements prepared by the Machinebuilding Plant to test whether it meets the going concern principle and is able to repay its debts within the timelines set forth in contracts if the court issues an unfavorable ruling and imposes penalties.

Looking through the register of disqualified persons ${ }^{3}$, business entities may detect whether the would-be counterparty's executive body consists of any disqualified persons (company check). Checking the source ${ }^{4}$, business entities may run through the list of disqualified persons to possibly locate the counterparty's top managers (citizen verification). We suggest documenting the results of such checks in the proposed form of the internal controller's working document as showed in Table 4.

Checking the register of material facts ${ }^{5}$, business entities may learn about net assets, results of audits, pledged property. Findings of internal control are given in the proposed working documents, Check of Register of Material Facts (Table 5).

Searching through the log of mass business registration addresses (the location is qualified as such if it serves as the registered seat for 10 or more companies) ${ }^{6}$, it is possible to figure out the number of legal entities registered at the address in question. What also matters is to sear ch for information about legal entities having taxes in arrears and/or failing to submit tax

\footnotetext{
${ }^{3}$ Federal Tax Service of the Russian Federation. Search through the register of disqualified persons.

URL: https://service.nalog.ru/disqualified.do (In Russ.)

${ }^{4}$ Federal Tax Service of the Russian Federation. Addresses indicated by several legal entities for the State registration as their registered seat. URL: https://service.nalog.ru/addrfind.do (In Russ.)

${ }^{5}$ Uniform federal register of legally valid data on performance of legal entities, individual entrepreneurs and other business agents (Fedresurs). URL: http://www.fedresurs.ru (In Russ.)

${ }^{6}$ Federal Tax Service of the Russian Federation. Data on mass business registration addresses. URL: https://service.nalog.ru/baddr.do (In Russ.)
}

returns for more than one year ${ }^{7}$. Findings are presented in the proposed working file of the internal controller, Check of Mass Business Registration Addresses Database (Table 6).

Business entities should be especially prudent when assessing the following aspects:

- the company's address serving as the registered seat for numerous business entities;

- substantial amounts of taxes due;

- the same person acting as the chief accountant and CEO;

- a short period of time between the official incorporation date and the conclusion of the contract with the supplier.

These aspects come under close scrutiny of financial functions, which should adhere to the statutory document ${ }^{8}$. The document enlists indicia of mala fide entities and rules for practicing the approach. To verify the creditworthiness of an entity, it is necessary to gather a set of documents (copies verified by the authorized person) before the contract is concluded or finished products, goods are shipped or services, work are delivered:

1) the Certificate of State Registration of the Legal Entity;

2) the Certificate of Tax Registration of the Legal Entity;

3) Articles of Association in the effective edition;

4) Executive Body Appointment Order (director, general manager);

5) Minutes of Executive Body Appointment (director, general manager);

6) lease contract for the registered address;

7) abstract from the Uniform State Register of Legal Entities as of the current date;

8) lease contract for warehouse and (or) production premises/facilities;

\footnotetext{
${ }^{7}$ Federal Tax Service of Russia. Data on legal entities having taxes in arrears and/or failing to submit tax returns. URL: https://service.nalog.ru/zd.do (In Russ.)

${ }^{8}$ Resolution of the Plenum of the Supreme Arbitration Court of the Russian Federation № 53 of October 12, 2006, On Arbitration Courts' Evaluation of Reasonableness of the Taxpayer's Tax Benefits. URL: http://www.consultant.ru/document/cons_doc_LAW_63894/ (In Russ.)
} 
9) information on the existence/non-existence of the official web site;

10) Balance Sheet;

11) tax returns;

12) bank account statement;

13) statement of specific tax treatment eligibility;

14) licenses (if the entity's activity is subject to licensing);

15) tax clearance statement;

16) copy of the executive body's passport details (director, general manager);

17) documents confirming title to motor vehicles;

18) contract for lease of motor vehicles or other documents confirming the physical availability of tangible resources for the declared activity;

19) information about the average headcount;

20) documents confirming the authorized person's entitlement to act as a signatory; copies of passport details of such persons.

It should be noted that the developing e-commerce made many buyers and sellers use Internet resources to seek and offer goods, work and services. Strengths can be found in every aspect of e-commerce. However, there are still many weaknesses which entail millions of losses for businesses. Sometimes Internet resources happen to lack reliability and transparency. There more frequently reoccur bogus websites repeating the information of renown companies. Modern technologies and their growth raises the state of alert among the e-commerce market actors. Online services can be used to verify the reliability and creditworthiness of counterparties before contracts are concluded, such as website trust flow checks (Yandex), online reputation and Internet safety service (WebMoney Advisor, Web of Trust), domain name search, online scams checks, antivirus software.

Users acquire additional information to verify the creditworthiness of their counterparties.

For example, using the Yandex service of trust flow check $^{9}$, the user inserts details in the search box. The details are processed online and converted into tables. They help evaluate the creditworthiness of a counterparty. Certainly, it will not be a 100-percent guarantee of partners' reliability but will expand the user's knowledge of the counterparty's reputation.

The above data sources help reveal the quality of counterparties, their solvency, integrity and evaluate the potential of further cooperation. If the business entity chooses to enter into contracts for supply, purchase and sale, it can refer to the findings of the analysis as described above to determine the appropriate format of settlements with the counterparty in order to mitigate possible risks in the future.

\footnotetext{
${ }^{9}$ Yandex service for checking the website trust flow. URL: https://xtool.ru
} 
Table 1

Publicly available sources on the Internet

\begin{tabular}{ll}
\hline Website & Aspects to be checked \\
\hline www.nalog.ru & Data verification in the Uniform State Register of Legal Entities \\
\hline http://kad.arbitr.ru & Check of commercial court files \\
\hline https://service.nalog.ru/disqualified.do & $\begin{array}{l}\text { Register of disqualified person to check whether the counterparty's top } \\
\text { managers are mentioned there }\end{array}$ \\
\hline https://service.nalog.ru/addrfind.do & Information about mass business registration addresses \\
\hline https://service.nalog.ru/baddr.do & $\begin{array}{l}\text { Data on legal entities which cannot be contacted at the address indicated } \\
\text { in the Uniform State Register of Legal Entities }\end{array}$ \\
\hline https://service.nalog.ru/zd.do & Data on entities failing to perform tax liabilities \\
\hline http://www.fedresurs.ru & Check of registers of material facts \\
\hline
\end{tabular}

Source:Authoring

Table 2

Working document, Check through the Uniform State Register of Legal Entities

\begin{tabular}{|c|c|c|c|c|}
\hline \multirow[t]{2}{*}{ Debtor's Tax ID } & \multicolumn{4}{|l|}{ Check results } \\
\hline & $\begin{array}{l}\text { Authorized capital, } \\
\text { RUB }\end{array}$ & Core activity & $\begin{array}{l}\text { Signatory of } \\
\text { financial documents }\end{array}$ & $\begin{array}{l}\text { Amendments to } \\
\text { incorporation documents }\end{array}$ \\
\hline $\begin{array}{l}\text { 52XXXXXXXX } \\
\text { PAO Machinebuilding Plant }\end{array}$ & $902,027,280$ & $\begin{array}{l}25.30 \text { Production of a steam } \\
\text { generating unit, other than } \\
\text { central heating boiler }\end{array}$ & - & - \\
\hline $\begin{array}{l}\text { 52XXXXXXXX } \\
\text { PAO Instrument Engineering Plant }\end{array}$ & $256,206,678$ & $\begin{array}{l}\text { 26.51.6 Production of other } \\
\text { devices, meters, equipment and } \\
\text { tools for measurements, control } \\
\text { and tests }\end{array}$ & Oleg M. Petrov & - \\
\hline $\begin{array}{l}\text { 52XXXXXXXX } \\
\text { 000 Khlebozavod }\end{array}$ & $27,819,450$ & $\begin{array}{l}10.71 \text { Production of non- } \\
\text { durable bread, pastry, cakes and } \\
\text { baked confectionery products }\end{array}$ & Aleksei A. Ivanov & - \\
\hline
\end{tabular}

Note. Business data are conditional.

Source:Authoring

\section{Table 3}

Working document of the internal controller, Commercial Court Case Files Check

\begin{tabular}{|c|c|c|c|c|}
\hline \multirow{2}{*}{$\begin{array}{l}\text { Taxpaer's ID/Name of Debtor } \\
\text { (Counterparty) }\end{array}$} & \multicolumn{4}{|l|}{ Check results } \\
\hline & Case Number & Current phase / judge & Claimant & Defendant \\
\hline $\begin{array}{l}\text { 52XXXXXXXX } \\
\text { PAO Machinebuilding Plant }\end{array}$ & $\begin{array}{l}23.06 .2017 \\
A 00-00000 / 2017\end{array}$ & $\begin{array}{l}\text { Arbitration Court } \\
\text { of Moscow, } \\
\text { A.G. Metel'kova }\end{array}$ & $\begin{array}{l}\text { TRIADA Federal } \\
\text { State Unitary } \\
\text { State-Financed } \\
\text { Enterprise }\end{array}$ & PAO Machinebuilding Plant \\
\hline $\begin{array}{l}52 X X X X X X X X \\
\text { PAO Instrument Engineering Plant }\end{array}$ & No data & & & \\
\hline $\begin{array}{l}\text { 52XXXXXXXX } \\
000 \text { Khlebozavod }\end{array}$ & No data & & & \\
\hline
\end{tabular}

Source: Authoring based on the web service. URL: http://kad.arbitr.ru/ (In Russ.)

Please cite this article as: Shatina E.N., Kozmenkova S.V., Frolova E.B. Internal Control: Methodological Distinctions of Counterparty 
Table 4

Working document, Check of Register of Disqualified Persons

\begin{tabular}{llll}
\hline Taxpayer's ID of Debtor & Name & Results of Check \\
\cline { 2 - 4 } & & $\begin{array}{l}\text { Disqualified persons in the executive } \\
\text { body of the counterparty } \\
\text { (organization) }\end{array}$ & Disqualified persons (CE0) \\
\hline $52 X X X X X X X X$ & PAO Machinebuilding Plant & - & - \\
\hline $52 X X X X X X X X$ & PAO Instrument Engineering Plant & - & - \\
\hline $52 X X X X X X X X$ & 000 Khlebozavod & - & - \\
\hline
\end{tabular}

Source:Authoring based on URL: https://service.nalog.ru/disqualified.do; URL: https://service.nalog.ru/addrfind.do

\section{Table 5}

Working document, Check of Register of Material Facts

\begin{tabular}{|c|c|c|c|c|}
\hline \multirow[t]{2}{*}{ Taxpayer's ID of Debtor } & \multicolumn{4}{|c|}{ Results of Check } \\
\hline & $\begin{array}{l}\text { Net assets, } \\
\text { thousand RUB }\end{array}$ & Audit Report on financial statements & Pledged property & $\begin{array}{l}\text { Information on } \\
\text { restructuring/dissolut } \\
\text { ion }\end{array}$ \\
\hline $\begin{array}{l}\text { 52XXXXXXXX } \\
\text { PAO Machinebuilding } \\
\text { Plant }\end{array}$ & Not available & No data & $\begin{array}{l}\text { 1. Toyota Highlander } \\
\text { 2. Lexus LX } 570\end{array}$ & None \\
\hline $\begin{array}{l}\text { 52XXXXXXXX } \\
\text { PAO Instrument } \\
\text { Engineering Plant }\end{array}$ & 4,290 & $\begin{array}{l}\text { Financial statements, in material } \\
\text { respects, give a fair and true view of the } \\
\text { financial position of PAO Instrument } \\
\text { Engineering Plant as of } 31.12 .2017, \\
\text { results of its financial and business } \\
\text { operations for FY } 2017 \text { in compliance } \\
\text { with the Russian rules for financial } \\
\text { reporting }\end{array}$ & None & None \\
\hline $\begin{array}{l}\text { 52XXXXXXXX } \\
000 \text { Khlebozavod }\end{array}$ & No data & No data & No data & None \\
\hline
\end{tabular}

Source:Authoring based on source data: URL: http://www.fedresurs.ru

Table 6

Working document, Check of Mass Business Registration Addresses Database

\begin{tabular}{ll}
\hline Debtor, its address & Number of registered personalities \\
\hline PAO Machinebuilding Plant & No data \\
\hline PAO Instrument Engineering Plant & No data \\
\hline 000 Khlebozavod & No data \\
\hline
\end{tabular}

Source:Authoring based on the website. URL: https://service.nalog.ru/addrfind.do

Please cite this article as: Shatina E.N., Kozmenkova S.V., Frolova E.B. Internal Control: Methodological Distinctions of Counterparty 


\section{References}

1. Ivashkevich V.B., Semenova I.M. Uchet i analiz debitorskoi i kreditorskoi zadolzhennosti [Accounting and analysis of accounts receivable and accounts payable]. Moscow, Bukhgalterskii uchet Publ., 2003, 189 p.

2. Kulikova L.I. [Formation of reserves for doubtful debts: accounting and tax accounting]. Bukhgalterskii uchet = Accounting, 2011, no. 7, pp. 16-22. (In Russ.)

3. Klychova G.S., Khamidullin G.S. [Accounts receivable: the essence and definition]. Bukhgalterskii uchet $v$ byudzhetnykh i nekommercheskikh organizatsiyakh = Accounting in Budgetary and Non-Profit Organizations, 2016, no. 16, pp. 40-45. URL: https://cyberleninka.ru/article/n/debitorskaya-zadolzhennost-suschnost-i-opredelenie (In Russ.)

4. Klychova G.S., Khamidullin G.S. [Current issues in monitoring and control of receivables]. Vestnik Kazanskogo gosudarstvennogo agrarnogo universiteta = Vestnik of Kazan State Agrarian University, 2016, vol. 11, no. 1, pp. 109-113. (In Russ.) URL: https://doi.org/10.12737/19337

5. Kemaeva S.A. [Formation of reserves for doubtful debts: the Russian and international accounting practices]. Ekonomicheskii analiz: teoriya i praktika = Economic Analysis: Theory and Practice, 2005, no. 5, pp. 47-52. URL: https://cyberleninka.ru/article/n/formirovanie-rezervov-po-somnitelnym-dolgam-v-rossiyskoy-imezhdunarodnoy-uchetnoy-praktike (In Russ.)

6. Kemaeva S.A. [Comparative analysis of accounts receivable and payable in accordance with the Russian and international financial reporting standards]. Vestnik Nizhegorodskogo universiteta im. N.I. Lobachevskogo. Seriya: Ekonomika i finansy = Vestnik of Lobachevsky University of Nizhny Novgorod. Series: Economics and Finance, 2004, no. 1, pp. 180-186.

URL: http://www.unn.ru/pages/issues/vestnik/99990193_West_econ_finans_2004_1(5)/B_40.pdf (In Russ.)

7. Sungatullina L.B., Klement'ev M.I. [Monitoring of accounts receivable to ensure the financial stability of the organization]. Bukhgalterskii uchet $v$ byudzhetnykh i nekommercheskikh organizatsiyakh = Accounting in Budgetary and Non-Profit Organizations, 2017, no. 10, pp. 2-9. URL: https://cyberleninka.ru/article/n/kontrol-zadebitorskoy-zadolzhennostyu-dlya-obespecheniya-finansovoy-ustoychivosti-organizatsii (In Russ.)

8. Gorshkova N.V., Khmeleva O.V. [Assessment of the status of receivables and payables in the agro-food holdings]. Mezhdunarodnyi bukhgalterskii uchet = International Accounting, 2012, no. 22, pp. 27-38.

URL: https://cyberleninka.ru/article/n/otsenka-sostoyaniya-debitorskoy-i-kreditorskoy-zadolzhennosti-vagroprodovolstvennyh-holdingah (In Russ.)

9. Artemova I.V. [Overdue accounts receivable and accounts payable]. Sovetnik v sfere obrazovaniya, 2015, no. 7, pp. 19-24. URL: https://www.referent.ru/40/10560 (In Russ.)

10. Vedernikova E.A. [Accounts payable in the system of economic security of companies]. Ekonomika i sotsium, 2017, no. 1-1, pp. 283-286. (In Russ.) URL: https://iupr.ru/domains_data/files/sborniki_jurnal/Zhurnal \%20_1(32)\%202017\%201.pdf

11. Grebennikova V.A., Ponchishkina A.N. [Payables Russian organizations: assessment according to the financial statements and approaches to management]. Ekonomika i predprinimatel'stvo = Journal of Economy and Entrepreneurship, 2016, no. 4-2, pp. 165-171. (In Russ.)

12. Kopein V.V. [Accounts payable of enterprises as a marker of financial security]. Novaya nauka: Sovremennoe sostoyanie i puti razvitiya = The New Science: The Current State and Development Trends, 2016, no. 10-1, pp. 78-80. (In Russ.)

13. Markova N.A. [The policy of creditor debts management of the organization]. Vestnik Volzhskoi gosudarstvennoi akademii vodnogo transporta = Vestnik of Volga State Academy of Water Transport, 2007, no. 21, pp. 92-96. (In Russ.)

Please cite this article as: Shatina E.N., Kozmenkova S.V., Frolova E.B. Internal Control: Methodological Distinctions of Counterparty 
14. Sapozhnikova N.G., Trunaeva O.Yu. [On control of accounts receivable and accounts payable of the corporation]. Innovatsionnaya nauka, 2016, no. 9, pp. 152-157. URL: https://cyberleninka.ru/article/n/okontrole-debitorskoy-i-kreditorskoy-zadolzhennosti-korporatsii (In Russ.)

15. Kovaleva N.N., Ermakova L.V., Mel'gui A.E. [Features of the audit of settlements with buyers and customers]. Ekonomika i menedzhment innovatsionnykh tekhnologii, 2016, no. 10, pp. 77-79. (In Russ.) URL: http://ekonomika.snauka.ru/2016/10/12639

16. Chaplygina M.A., Pol'skaya G.A., Vinogradova N.I. [Practical aspects of the improvement of an integrated approach to monitoring the quality of receivables]. Vestnik Belgorodskogo universiteta kooperatsii, ekonomiki $i$ prava $=$ Herald of Belgorod University of Cooperation, Economics and Law, 2014, no. 1, pp. 366-373. URL: http://vestnik.bukep.ru/articles_pages/articles/2014/2014-1/Articles_366-373.pdf (In Russ.)

17. Mikhalenok N.O., Shnaider O.V. [Accounts receivable and accounts payable: principles of analysis, classifications and methods of internal control]. Azimut nauchnykh issledovanii: ekonomika $i$ upravlenie = ASR: Economics and Management, 2018, vol. 7, no. 1, pp. 191-194. (In Russ.)

18. Shakhmanova B.A. [Estimation of contractual policy for audit of receivables in the interconnected trade organizations]. Vestnik NGUEU = Vestnik NSUEM, 2014, no. 1, pp. 145-156.

URL: https://nsuem.elpub.ru/jour/article/view/256/254 (In Russ.)

\section{Conflict-of-interest notification}

We, the authors of this article, bindingly and explicitly declare of the partial and total lack of actual or potential conflict of interest with any other third party whatsoever, which may arise as a result of the publication of this article. This statement relates to the study, data collection and interpretation, writing and preparation of the article, and the decision to submit the manuscript for publication. 